\title{
O debate inesgotável: causas sociais e biológicas do colapso demográfico de populações ameríndias no século XVI
}

\author{
The inexhaustible debate: social and biological causes of the demographic collapse of \\ Amerindian populations in the sixteenth century
}

\author{
Ricardo Waizbort (D) \\ Instituto Oswaldo Cruz. Fundação Oswaldo Cruz. Rio de Janeiro, Rio de Janeiro, Brasil
}

\begin{abstract}
Resumo: No século $X X$, estimativas populacionais para o hemisfério ocidental, as Américas, sobre o período que antecedeu à chegada de Colombo variaram entre dez milhões até mais de cem milhões. Essa grande discrepância é fundamental para avaliar o peso das epidemias na brusca redução demográfica que se seguiu. O fato é que houve um colapso demográfico de populações de ameríndios que viviam sobretudo, mas não exclusivamente, no atual México e na América Andina durante o século XVI. A decisão de certos historiadores de eleger as epidemias como causa distante e suficiente desse colapso populacional dissimularia, segundo outros autores, uma espécie de 'determinismo imunológico', isentando os espanhóis de responsabilidade e modelando formas de enfrentar problemas de saúde que se manifestam ainda hoje. Partindo de literatura específica, desenvolvemos a ideia de que é possível contribuir para compreender esse colapso, conjugando 'causas distantes' (como as epidemias) com 'causas próximas' (como a violência dos espanhóis e a desestruturação dos sistemas de subsistência e reprodução dos ameríndios), duas categorias oriundas da biologia evolutiva e da medicina evolutiva. Na realidade, pretendemos defender essa síntese, que já vem sendo feita por certos autores, embora não nos termos das categorias causais que manipulamos aqui.
\end{abstract}

Palavras-chave: Conquista espanhola. Ameríndios. Colapso populacional. Epidemias em solo virgem. Medicina evolutiva. Determinismo imunológico.

Abstract: In the twentieth century, population estimates for the Western Hemisphere (Americas) before the arrival of Colombus ranged from ten million to over one hundred million. This large discrepancy is essential in assessing the role of epidemics in the sharp demographic decline that followed. In fact, there was a demographic collapse of Amerindian populations who lived mainly (but not exclusively) in present-day Mexico and the Andean region during the sixteenth century. The fact that some historians chose to indicate epidemics as a distant and sufficient cause of this population collapse conceals (in the opinion of other authors) a type of "immunological determinism" which absolves the Spaniards of responsibility and models ways of addressing health problems that still exist today. This study is based on specific literature and develops the idea that this collapse can be understood by combining "distant causes" (such as epidemics) with "near causes" (such as the violence of the Spaniards and the destruction of Amerindian subsistence and reproductive systems), two categories from evolutionary biology and evolutionary medicine. Our goal is to defend this synthesis, which has already been developed by certain authors, although not in terms of the causal categories we utilize here.

Keywords: Spanish conquest. Amerindians. Population collapse. Epidemics in virgin territories. Evolutionary medicine. Immunological determinism.

WAIZBORT, Ricardo. O debate inesgotável: causas sociais e biológicas do colapso demográfico de populações ameríndias no século XVI. Boletim do Museu Paraense Emílio Goeldi. Ciências Humanas, Belém, v. 14, n. 3, p. 921-941, set.-dez. 2019. DOI: http://dx.doi.org/ 10.1590/1981.81222019000300012.

Autor para correspondência: Ricardo Waizbort. Fundação Oswaldo Cruz. Instituto Oswaldo Cruz. Laboratório de Avaliação em Ensino e Filosofia das Biociências. Avenida Brasil, 4365, Pavilhão 108, sala 31. Rio de Janeiro, RJ, Brasil. CEP 21040-360 (ricardowaizbort@ yahoo.com.br; ricardopgebs@gmail.com).

Recebido em 30/01/2019

Aprovado em 15/04/2019

(c) (i)

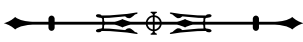


Nos caminhos jazem dardos rotos, os cabelos estão espalhados.

Destelhadas estão as casas, ensanguentadas têm seus muros.

Vermes pululam pelas ruas e praças e as paredes estão salpicadas de miolos. Vermelhas estão as águas, estão como que tingidas, e quando as bebemos, é como se bebêssemos água de salitre!

Não havia então o pecado não havia então a doença, não havia a dor dos ossos, não havia a febre pelo ouro, não havia a varíola².

\section{INTRODUÇÃO}

O processo da conquista espanhola ao longo do século XVI foi registrado desde o princípio por vários cronistas espanhóis: Hernan Cortes (1485-1547), nas "Cartas de relación"; Bernal Díaz (1492-1581), em "La historia verdadera de la Nueva España"; Bartolomeu de las Casas (1474-1566), na "Historia general de las indias"; Bernardino de Sahagún (ca. 1499-1590), na "Historia general de las Casas de la Nueva España"; Frei Toribio de Benavente (ca. 1482-1569), conhecido como Motolinia, na "Historia de las Indias de la Nueva España"; Francisco López de Gomara (1511-1566), na "Historia general de las Indias", para ficar apenas com alguns dos mais conhecidos (Restall, 2006; Livi-Bacci, 2007; Todorov, 2010). Historiadores das populações colombianas e pré-colombianas reconhecem também outras fontes históricas que representaram a conquista como cronistas ameríndios e mestiços, tanto em línguas nativas e espanhol (aprendido pelos nativos) quanto em combinações variadas de idiomas (Léon-Portilla, 1985; Sánchez-Albornoz, 2012, 2003; Restall, 2006; Cook, S.; Borah, 1977; Livi-Bacci, 2007). A literatura oral das etnias pré-colombianas também é relativamente bem conhecida, assim como suas pinturas ideográficas (Cook, S.; Borah, 1977; Léon-Portilla, 1985; Livi-Bacci, 2007). Ao longo dos séculos XVI, XVII e XVIII, leituras e releituras dessas fontes multifacetadas enriqueceram, ao mesmo tempo que tornaram mais intrincadas, as interpretações sobre o que, de fato, aconteceu nesse encontro entre europeus e nativos americanos. Essa história é marcada por uma evidente hecatombe populacional registrada em muitos desses documentos, ainda que fragmentária e episodicamente. Não se propõe aqui tratar das intrincadas fontes primárias e secundárias referentes a esse processo que continua a suscitar perguntas, mas apresentar uma revisão de como determinados historiadores interpretam a importância das doenças epidêmicas, e de que forma uma interpretação enriquecida com categorias da biologia evolutiva pode contribuir para uma compreensão menos imperfeita sobre esse fenômeno. Ao longo do presente artigo, muitas vezes nos referiremos aos nativos das Américas como ameríndios, embora reconheçamos os limites e os problemas dessa designação, além de reconhecer que ela necessariamente oculta a diversidade e a heterogeneidade dos grupos étnicos que viviam nas Américas, antes da chegada dos espanhóis, ameríndios dos quais são apenas mais notórios astecas, incas e maias (Mann, 2007). Não pretendemos também lidar com o problema da hecatombe populacional fazendo referência ao hemisfério ocidental (Novo Mundo) como um todo. Dada a complexa heterogeneidade e diversidade biocultural das populações que aqui viviam, optamos por estabelecer um foco mais específico no que ocorreu no México, em termos de densidade demográfica, ao longo do século XVI, porque há vários estudos importantes sobre a dizimação dos astecas, além de muitas controvérsias. Mas não iremos evitar referências ao hemisfério ocidental como um todo e a grupos étnicos específicos, que também tiveram suas populações ceifadas a partir do encontro com os europeus.

No livro "Sete mitos da conquista espanhola", o historiador Mathew Restall destrinchou uma série de narrativas tradicionais associadas à derrota e à morte, em fins do século XV e ao longo do seguinte, de certamente

Cantares mexicanos (In: Léon-Portilla, 1985, p. 148).

2 Chilam Balam di Chumayel (In: Livi-Bacci, 2007, p. 58). 
dezenas de milhões de ameríndios de culturas distintas, sobretudo dos impérios Asteca, Inca e Maia, distribuídos de forma heterogênea por várias regiões das Américas Central e do Sul (Livi-Bacci, 2011). Os sete mitos a que se refere Restall (2006) são: 1) os conquistadores europeus, embora em número muito menor, eram homens excepcionais; 2) tais conquistadores eram soldados bem treinados, que faziam parte dos exércitos do Rei de Espanha; 3) a conquista das terras americanas se deu essencialmente por homens brancos; 4) a conclusão do processo de conquista foi rápida, em termos de anos, no máximo décadas; 5) as falhas e os êxitos de comunicação favoreceram os conquistadores, em completo detrimento dos ameríndios; 6) a conquista devastou e desolou os conquistados, e nada trouxe de significativo para as culturas nativas das Américas, que teriam sido varridas da face da Terra; 7) por fim, o mito, que de certa forma engloba todos os outros, de que a conquista ocorreu por que os europeus eram superiores militar, econômica, tecnológica, moral e religiosamente. Note-se que todas essas ficções "[...] tidas por verdadeiras [...]" (Restall, 2006, p. 19) mobilizam causas sociais ou humanas.

Restall (2006, p. 240) constrói uma rica narrativa crítica em que, desemaranhando esses mitos, emerge uma trilogia de causas que "[...] responde por boa parte do resultado da Conquista [...]": "[...] doenças, desunião entre os indígenas e as espadas espanholas". Restall (2006) mostra que um bom número de integrantes de diferentes etnias ameríndias, assim como de populações africanas, ajudou os espanhóis no combate a impérios nativos que estavam estabelecidos, como o império Asteca, no México (Tenochtitlán), e o Inca, em Cajamarca. Esses ameríndios receberam vantagens imediatas próprias. Por outro lado, as armas de fogo, em geral, eram grandes, difíceis de manejar e transportar, por causa da sinuosidade topográfica das regiões invadidas; além disso, a pólvora estava quase sempre úmida, dificultando os disparos. Sendo assim, as espadas eram mais efetivas do que as armas de fogo. Restall (2006, p. 235) também expressa a ideia de que houve um colapso populacional que afligiu os ameríndios:
As Américas ficaram isoladas do resto do mundo por dez mil anos. Em virtude do maior volume populacional e da maior variedade de animais domésticos (dos quais se originam doenças como varíola, sarampo e gripe) do Velho Mundo, os europeus e africanos desembarcaram no Novo Mundo carregados com toda uma gama de germes mortais. Embora estes ainda provocassem mortes no Velho Mundo, seus habitantes haviam desenvolvido níveis de imunidade relativamente altos em comparação com os americanos nativos, que morriam num ritmo e números assombrosos. No século e meio que se seguiu à primeira viagem de Colombo, a população indígena da América sofrera uma redução de $90 \%$.

Perceba-se que, aqui, Restall (2006) não apresenta uma estimativa populacional para o Novo Mundo, mas se refere a uma extraordinária redução populacioanal de noventa por cento. Ele registra em nota que

[...] existem muitas divergências quanto ao tamanho das populacões nativas nas Américas antigas; estimativas das perdas do século XVI variam abaixo e acima do número mediano de 40 milhões. Mesmo num patamar de 25 milhões, digamos, o índice de mortalidade ainda seria maior que o da Peste Negra europeia, por exemplo [... (Restall, 2006, p. 301).

Essa grande mortalidade teria sido causada fundamentalmente por epidemias.

Mobilizar doenças epidêmicas como a causa distante, evolutiva, da morte de dezenas de milhões de ameríndios figura como uma explicação predominante na historiografia, a partir da década de 1960 (Dobyns, 1966; Cook, S.; Borah, 1977; Crosby, 1976; MacNeill, 1976; Brooks, 1993; Sánchez-Albornoz, 2003, 2012; Malvido, 2003; Jones, 2003, 2016; Livi-Bacci, 2003, 2006, 2007). A ideia de que epidemias trazidas pelos europeus foram a causa primordial do colapso demográfico dos ameríndios do hemisfério ocidental é conhecida como a hipótese da epidemia em solo virgem, e é atribuída, independentemente, a Alfred Crosby e William MacNeill (Crosby, 1976; MacNeill, 1976; Jones, 2003, 2016; Sánchez-Albornoz, 2003; LiviBacci, 2007). No entanto, segundo Assadourian (1989, p. 420, tradução nossa), foi um "[...] ensaio de Borah (1962)

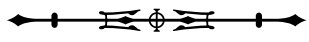


que decidiu sua ampla aceitação [da hipótese]”. Borah é um dos integrantes da escola de Berkeley, formada por demógrafos históricos que revisaram as cifras para o tamanho das populações antes da chegada de Colombo, tendo em conta que os números populacionais para os fins do século XVI eram relativamente bem conhecidos. Assadourian (1989) recusa a primazia da hipótese da epidemia em solo virgem, evidenciando o papel da política colonial sobre o trabalho dos ameríndios nas minas de ouro e prata, como outra das causas que contribuíram para o colapso demográfico. Autores como Newson (1985), Brooks (1993), Jones (2003, 2016), Livi-Bacci (2003, 2006, 2007), Henige (2008) e Nash (2014) também recusam a ideia de que as epidemias possam sozinhas explicar tamanho colapso populacional. Também defenderemos que uma explicação para o fenômeno da hecatombe populacional não pode atribuir apenas às doenças esse resultado desastroso, embora sem elas não seja possível compreendê-lo. A explicação epidemiológica oculta uma forma de compreender as epidemias que ignora as circunstâncias ecológicas e sociais específicas que, no mínimo, pavimentaram o caminho da destruição demográfica. E que o trágico desfecho populacional não era necessário, não foi determinado pela chegada das epidemias nas Américas, pois há exemplos de epidemias entre ameríndios que foram trágicas, mas não desastrosas (Livi-Bacci, 2006; Jones, 2016).

Em "Armas, germes e aço", Jared Diamond se apropriou entusiasmadamente da hipótese da epidemia em solo virgem como base para estabelecer um padrão histórico apoiado nas diferenças biológicas, imunológicas, entre os espanhóis e os ameríndios, que justificariam a conquista de tantos por tão poucos (Diamond, 2009). O livro refuta, segundo o próprio autor, a ideia de que questões de raça estariam relacionadas com a conquista espanhola. Para Diamond (2009), a conquista não teria sido decorrente de uma suposta inteligência ou capacidade racial superior do homem branco europeu. Ele argumenta que uma espécie de fato histórico - a imunidade dos espanhóis para certas doenças, como varíola, sarampo, entre outras, e a 'virgindade' imunológica dos amerínidos para as mesmas enfermidades - determinou os destinos da conquista. Esse argumento, todavia, ignora uma importante distinção da medicina evolutiva, oriunda da biologia evolutiva, entre 'causas próximas' e 'causas distantes' (Mayr, 1961; Williams; Nesse, 1991), estabelecendo a primazia de causas distantes, evolutivas e geográficas, para explicar a conquista com toda a sua carga de destruição de populações e culturas. Ao tomar a decisão de identificar as epidemias como a causa fundamental do colapso demográfico, Diamond (2009) estaria incorrendo no que Jones chama de "[...] determinismo imunológico [...]" (Jones, 2003, p. 708, 710, 713, tradução nossa). Por outro lado, para os adeptos da medicina evolutiva, a explicação de qualquer fenômeno biológico deve articular causas distantes evolutivas com causas próximas funcionais ou fisiológicas (Williams; Nesse, 1991; Perlman, 2013).

A hipótese da epidemia em solo virgem parece uma explicação irretocável para a grande devastação humana, sobretudo em cenários de estimativas populacionais pré-contato muito altas. Na primeira parte deste artigo, apresentamos sumariamente a medicina evolutiva, pois ela maneja, no campo da saúde, as categorias de 'causas próximas' e 'causas distantes' como explicações para vários traços adaptativos da espécie humana e também para muitas doenças. Doenças não são adaptações. Todavia, no que toca à relação entre parasitos e hospedeiros, há muitas adaptações evolutivas envolvidas, tanto por parte das populações de patógenos quanto na de hospedeiros humanos. Quando se diz que os ameríndios eram imunologicamente virgens aos patógenos trazidos pelos europeus, isso significa que eles não possuíam defesas imunológicas presentes nos europeus. A princípio, essas defesas seriam adaptações genéticas dos europeus, que evoluíram ao longo de séculos em contato com parasitos (agentes etiológicos da varíola, do sarampo, do tifo, entre muitas outras doenças infecciosas), conferindo-lhes uma imunidade inata. Mas, segundo um autor como Jones $(2003,2016)$, é preciso entender melhor, 
biologicamente, o que se está dizendo quando se afirma que certas populações são imunologicamente virgens em relação a determinados patógenos. Como veremos, a ideia de que os ameríndios seriam imunologicamente virgens tem sido colocada em dúvida (Jones, 2003, 2016; Livi-Bacci, 2007). Outras causas devem ser mobilizadas.

Para a medicina evolutiva, a seleção natural não promove nos humanos, e em nenhuma outra espécie, a saúde em si mesma ou a longevidade, mas o sucesso reprodutivo. Assim, as epidemias do século XVI devastaram as populações humanas por que os parasitos encontraram condições ambientais (ecológicas, sociais), nos corpos dos ameríndios, de se reproduzirem e serem transmitidos, até que o estoque de indivíduos sensíveis às doenças estivesse reduzido demais para manter as populações dos parasitos. Na segunda parte, apresentamos a hipótese da epidemia em solo virgem tal como ela aparece no argumento de Diamond (2009), no livro supracitado, em relação à importância, absoluta ou relativa, das epidemias como explicação do colapso populacional dos ameríndios. Nos importamos aqui com Diamond por que seu "Armas, germes e aço" despertou comentários, ainda que muito críticos, em uma série de autores que lidam com o colapso demográfico dos ameríndios no século XVI (Jones, 2003, 2016; Nash, 2014; Correia, 2013; Livi-Bacci, 2011, 2007, 2006, 2003; Henige, 2008). Além disso, o livro permanece com grande circulação, justificando o lançamento, em 2017, de edição comemorativa de 20 anos da primeira edição.

Na terceira parte, mobilizamos uma bibliografia que critica explicitamente a hipótese da epidemia em solo virgem, o que nos deu esteio para argumentar sobre as virtudes de articular causas distantes com causas próximas. Apontamos autores como Carlos Sempat Assadourian, Nicolás Sánchez-Albornoz, Massimo Livi-Bacci, David Jones, entre outros, que, ao promoverem a articulação das epidemias com fatores sociais, acabam estimulando a interação entre causas distantes (imunológicas, biogeográficas, evolutivas) e causas próximas (violência dos espanhóis, fome, pobreza, tributos altos). Esses autores não usam os conceitos de causas próximas e causas distantes, mas nós os interpretamos à luz dessas categorias mobilizadas pela medicina evolutiva, visto que eles inserem o fenômeno histórico em questão em um ambiente ecológico e social que vai muito além das relações diretas entre parasitos e hospedeiros. Verificamos que tais autores promovem justa crítica a uma forma de compreender a história que embute em si mesma formas de determinismo biológico.

\section{A MEDICINA EVOLUTIVA}

A medicina evolutiva é a tentativa de complementar a medicina tradicional - que busca as causas próximas ou fisiológicas das doenças - com a estrutura da teoria da evolução por seleção natural - que procura pelas causas distantes ou históricas das estruturas adaptativas e dos comportamentos adaptativos, que nos capacitam a nos mantermos vivos e sexualmente ativos. Embora Ernst Mayr não tenha sido quem pela primeira vez empregou esse par categorial, ele foi um dos seus promotores mais importantes (Caponi, 2014; Mayr, 1961). Além disso, o programa adaptacionista, tal como definido e defendido por Mayr (1983), está declaradamente na base da medicina evolutiva (Nesse; Williams, 1997, p. 19-23). O programa adaptacionista parte da hipótese de que estruturas físicas, macro e microscópicas, e comportamentos funcionais, que decidamente contribuem para que indivíduos e espécies permaneçam vivos até cumprirem sua 'missão' reprodutiva, são adaptações resultantes do processo de seleção natural.

A medicina evolutiva foi deflagrada pelo trabalho fundador de Williams e Nesse (1991) e, desde então, cresceu exponencialmente, com a publicação de literalmente centenas de artigos e muitas dezenas de livros, além de vários sítios na internet (Alcock, 2012; Waizbort; Luz, 2017). No artigo, Williams e Nesse (1991) argumentam que as explicações por causas próximas ou fisiológicas que a medicina mais tradicional mobiliza são incompletas e precisariam ser complementadas com explicações que mobilizem causas distantes ou evolutivas.

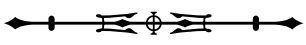


Eles usaram, então, um exemplo de uma característica adaptativa, a presença de sete vértebras cervicais no pescoço humano, perguntando se a física e a química, nas quais está apoiada a medicina tradicional, poderiam explicar esse número. A resposta, a princípio, é positiva: as sete vértebras surgiriam de uma série de eventos de desenvolvimento, de natureza material, bem entendidas pelas ciências que mobilizam causas próximas, como a fisiologia, a embriologia e a genética. Entrentanto, para eles, essa explicação está incompleta. Eles argumentam que:

Uma explicação completa de como sete vértebras cervicias são normalmente produzidas pelo zigoto humano deixa intocada a questão de por que o DNA do zigoto deve ser assim programado. Por que ele não é programado para produzir seis ou oito vértebras cervicias? E por que o zigoto deve ser capaz de produzir um pescoço funcionalmente adequado? Essas duas últimas questões encontram suas respostas nos conceitos de filogenia e seleção natural, respectivamente. Tais respostas não são alternativas às respostas dadas pela fisiologia e pela embriologia, elas são respostas dadas a diferentes tipos de questões. (Williams; Nesse, 1991, p. 2, tradução nossa).

O par de categorias 'causas próximas' e 'causas distantes' está diretamente relacionado aos conceitos de 'adaptação fisiológica' e 'adaptação evolutiva'. Enquanto a adaptação fisológica é a resposta fisiológica de 'um' corpo a determinadas circunstâncias ambientais, próximas, a adaptação evolutiva é o resultado de um processo de seleção natural que provê indivíduos de populações biológicas exatamente com estruturas e comportamentos que realizam funções específicas (Mayr, 1961). Por exemplo, ao entrarmos em um ambiente com pouca luminosidade, a princípio, nossa visão não distingue bem os objetos, mas, aos poucos, começa a ser capaz de divisá-los menos imperfeitamente. $\bigcirc$ ajuste individual que cada um de nós operamos ao entrarmos em um lugar escuro é uma adaptação fisiológica. Já a 'capacidade' de fazer esses ajustes, mediada pela presença de olhos, células neuronais e módulos cerebrais específicos e especializados, é uma adaptação evolutiva, resultado de processos populacionais e intergeracionais, que envolvem a chamada seleção natural das variantes favoráveis. Assim, adaptações evolutivas são capacidades conferidas ao nosso corpo pela presença de estruturas e de comportamentos muito complexos, que, por sua vez, emergiram dentro das populações por intermédio de processos de reprodução diferenciada (Caponi, 2011).

Como já referido, desde o artigo de Williams e Nesse (1991), a medicina evolutiva, essa "[...] nova disciplina científica [...]" (Alcock, 2012, p. 10, tradução nossa), experimentou um crescimento exponencial, traduzido não só no número de artigos e de livros publicados ao longo das últimas três décadas e meia, como também nas reflexões sobre a importância de se introduzir, de um forma ou de outra, a medicina evolutiva no currículo dos graduandos de medicina e de outras carreiras relacionadas à saúde humana (Waizbort; Luz, 2017). Entretanto, até onde nos foi permitido identificar, só há uma referência da medicina evolutiva sobre a conquista espanhola, no livro "Evolutionary medicine":

[...] os europeus introduziram varíola, sarampo,
peste bubônica, influenza, tifo, difteria, febre
escarlate no Novo Mundo e na Polinésia,
onde essas doenças mataram de $20 \%$ a mais
que $90 \%$ dos nativos. O impacto da varíola
foi particularmente impressionante. (Stearns;
Medzhitov, 2016, p. 225, tradução nossa).

Os autores apresentam, em seguida, uma tabela com o elevado número de mortes por varíola em populações de determinadas localidades americanas (Espanha, Venezuela, México, Peru, Brasil, entre outras), em poucas décadas, ao longo do século XVI. As estimativas de morte para o México variam entre três e trinta milhões de habitantes para o período entre 1520 e 1521! Os autores não comentam essa discrepância. Como já assinalado, o tamanho das populações ameríndias na época da conquista é um tema ainda em disputa, que afeta sobremaneira a importância, relativa ou absoluta, das epidemias como causa, suficiente, do colapso demográfico. Steanrs e Medzhitov (2016) também não consideram possíveis causas próximas

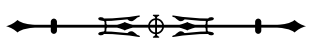


associadas a esses enormes níveis de mortalidade. A referência às epidemias do Novo Mundo, no século XVI, localiza-se em uma seção que discute certos desajustes evolutivos (mismatches), relacionados à emigração e à imigração. Os desajustes evolutivos podem ser temporais ou espaciais, no sentido de que uma determinada adaptação evolutiva, que emerge em um ambiente específico, pode se ver colocada em ambientes distintos, onde sua aptidão pode decair. Assim, diz-se que o corpo humano sofre com os desajustes entre o ambiente onde ele evoluiu e o ambiente moderno. A migração humana, por sua vez, cria uma espécie de desajuste espacial: "Migrantes introduzem doenças a populações que não as tinham previamente experimentado" (Stearns; Medzhitov, 2016, p. 225, tradução nossa). Patógenos vindo de outras regiões ocasionam surtos de mortalidade. Não há referência à imunidade ou à resistência genética ou adquirida, apenas a ideia de que populações humanas levam consigo parasitos a outras populações que não os abrigavam até então, e que tais populações são suscetíveis às doenças causadas por agentes etiológicos não conhecidos antes. Nosso objetivo é aprofundar um pouco a importância de se relacionar causas distantes biológicas com causas próximas sociais e também políticas.

\section{A HIPÓTESE DO SOLO VIRGEM, EM DIAMOND}

"Armas, germes e aço" não é um livro sobre a conquista espanhola, mas uma obra que procura mostrar por que o que se chamaria de cultura ocidental, por falta de uma categoria melhor, possui mais bens de consumo ('cargo', na língua de Yago, interlocutor de Diamond) do que a Nova Guiné e outros países do assim chamado terceiro mundo. Todavia, para Diamond, em seu livro, as doenças epidêmicas (os germes, do título) que dizimaram os ameríndios são basilares para um suposto padrão histórico que explicaria por que os europeus realizaram tantas conquistas sobre essas populações nativas. Por exemplo, Diamond argumenta que a vitória de Pizarro em Cajamarca foi precipitada por uma epidemia de varíola que, na sua rota de destruição, causou "[...] a disputa pelo trono entre líderes Incas, Ataualpa e seu meio-irmão, Huáscar [...] Não fosse a epidemia, os espanhóis teriam encontrado um império unido" (Diamond, 2009, p. 77). Ele usa esse seu raciocínio em relação aos incas para dar um salto indutivo em busca de um padrão histórico, processo epistemológico muito discutível entre historiadores (Calahan, 2005). Para Diamond (2009, p. 77):

A presença de Ataualpa em Cajamarca, portanto, destaca um fator-chave na história mundial: doenças transmitidas para pessoas sem imunidade por invasores com considerável imunidade. Varíola, sarampo, gripe, tifo, peste bubônica e outras doenças infecciosas, endêmicas na Europa, tiveram um papel decisivo nas conquistas europeias, dizimando muitos povos de outros continentes.

Segundo Diamond (2009, p. 77),

[...] em todas as Américas, as doenças introduzidas pelos europeus se alastraram de uma tribo para outra bem antes do avanço dos próprios europeus, matando um percentual calculado em cerca de 95\% da população nativa da América pré-colombiana.

Em outra parte do livro, ele reforça esse argumento da importância dos microorganismos para a dizimação de dezenas de milhões de astecas:

A importância dos micróbios letais na história
humana é bem ilustrada pelas conquistas europeias
e o despovoamento do Novo Mundo. Muito mais
ameríndios morreram abatidos pelos germes
eurasianos do que pelas armas e espadas europeias
nos campos de batalha. Esses germes minavam
a resistência indígena matando grande parte dos
índios e seus líderes e abalando o moral dos
sobreviventes. Em 1519, por exemplo, Cortes
desembarcou na costa do México com 600
espanhóis a fim de conquistar o temível império
asteca militarista com uma população de muitos
milhões. O fato de Cortes chegar à capital asteca
de Tenochtitlán, fugir depois da perda de "apenas"
dois terços de seu contingente e conseguir abrir
caminho lutando para voltar à costa demonstra a
superioridade militar espanhola e a ingenuidade
inicial dos astecas. Mas quando sobreveio o novo
ataque violento de Cortes, os astecas já não eram
mais ingênuos e lutaram com a máxima tenacidade.

A importância dos micróbios letais na história e o despovoamento do Novo Mundo. Muito mais ameríndios morreram abatidos pelos germes eurasianos do que pelas armas e espadas europeias nos campos de batalha. Esses germes minavam a resistência indígena matando grande parte dos índios e seus líderes e abalando o moral dos sobreviventes. Em 1519, por exemplo, Cortes desembarcou na costa do México com 600 espanhóis a fim de conquistar o temível império asteca militarista com uma população de muitos milhões. $\bigcirc$ fato de Cortes chegar à capital asteca de Tenochtitlán, fugir depois da perda de "apenas" dois terços de seu contingente e conseguir abrir caminho lutando para voltar à costa demonstra a superioridade militar espanhola e a ingenuidade ataque violento de Cortes, os astecas já não eram mais ingênuos e lutaram com a máxima tenacidade.

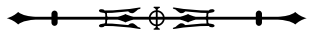


O que deu aos espanhóis uma vantagem decisiva foi a varíola, que chegou ao México em 1520 com um escravo contaminado procedente da Cuba espanhola ${ }^{3}$. A epidemia que veio em seguida matou quase a metade dos astecas, incluindo o imperador Cuitláhuac. Os sobreviventes astecas ficaram desmoralizados pela doença misteriosa que matava os índios e poupava os espanhóis, como que anunciando a invencibilidade dos espanhóis. Em 1618, a população inicial do México, de quase 20 milhões, caíra para cerca de 1,6 milhão. (Diamond, 2009, p. 210).

Apoiado nos proponentes da hipótese da epidemia em solo virgem (MacNeill, 1976; Crosby, 1976), Diamond (2009) argumenta que a varíola e as doenças trazidas pelos espanhóis são enfermidades humanas de multidões. Segundo ele, é o fato de que elas circulam entre muitas centenas de milhares de pessoas que as facultam a causar epidemias ou mesmo pandemias, capazes de exterminar grande parte de populações imunologicamente virgens. Para Diamond (2009), populações humanas grandes e densas são consequência da revolução agrícola de povos da região conhecida como 'crescente fértil', onde foram domesticados animais de grande porte. $\bigcirc$ excedente de produção resultante do controle de técnicas de agricultura permitiu a populações do crescente fértil a criação de grandes rebanhos, com grande importância alimentar e econômica. Os animais transmitiram suas doenças microbianas para os humanos e, ao longo da história, as gerações humanas, em contato com esses mamíferos de grande porte, acabaram desenvolvendo uma imunidade biológica, genética e inata, evolutivamente adquirida.

No século $X V I$, os povos europeus possuíam um número maior de animais domésticos do que os povos ameríndios, e essa circunstância estaria intimamente relacionada à imunidade dos europeus às epidemias e à sensibilidade dos ameríndios a essas doenças (Crosby, 1976; MacNeill, 1976; Diamond, 2009). Segundo Diamond (2009, p. 213):
A principal razão pela qual as epidemias de multidão letais não surgiram nas Américas fica clara quando fazemos uma pergunta simples. A partir de que micróbios elas poderiam ter se desenvolvido? [...] As doenças de multidão eurasianas se desenvolveram a partir das doenças dos rebanhos eurasianos domesticados. Enquanto muitos desses animais existiam na Eurásia, apenas cinco foram domesticados nas Américas: o peru no México e no sudoeste dos Estados Unidos, a lhama/alpaca e o porquinho-da-índia nos Andes, o pato-do-mato na América do Sul tropical, e o cachorro em todo o continente americano.

Também vimos que essa escassez extrema de animais domésticos no Novo Mundo reflete a escassez de material selvagem inicial. Cerca de 80 por cento dos grandes mamíferos selvagens das Américas foram extintos no final da última Era Glacial, por volta de 13 mil anos atrás. Os poucos domesticados que sobraram para os ameríndios não eram fontes prováveis de doenças de multidão, comparados às vacas e aos porcos. O pato-do-mato e o peru não vivem em grandes bandos e não são espécies que as pessoas costumam abraçar e afagar (como os cordeirinhos) e com as quais temos muito contato físico. Os porcos-da-índia podem ter contribuído com uma tripanossomíase, como a doença de Chagas ou a leishmaniose, para o nosso catálogo de aflições, mas isso não está confirmado. Inicialmente, mais surpreendente é a ausência de doenças humanas derivadas das lhamas (ou alpacas), que tendemos a considerar o equivalente andino do rebanho eurasiano. No entanto, houve quatro constatações que eliminam as lhamas como fonte de agentes patogênicos humanos: elas eram mantidas em rebanhos menores do que as ovelhas, as cabras e os porcos; sua quantidade total nunca foi nem remotamente tão grande quanto o total das populações de rebanhos domésticos eurasianos, já que a lhama nunca se espalhou além dos Andes; as pessoas não bebem (e por isso não são contaminadas) o leite de lhama; e as lhamas não são mantidas em lugares fechados, em contato direto com as pessoas.

Diamond (2009) argumenta, então, que a domesticação de animais (e de plantas) pôde ser mais ou menos livremente exportada no sentido leste-oeste (entre a Europa Central e Ásia Central, por exemplo), mas não no sentido norte-sul, uma vez que, em diferentes

3 Há questionamentos sobre a plausibilidade dessa narrativa de que foi um escravo negro que introduziu a varíola no México. Brooks (1993, p. 2), por exemplo, assinala que ninguém entre 1520 e 1530 pensava na varíola como uma doença transmissível. A ideia de contágio limitava-se, em grande parte, ao caso bíblico da lepra.

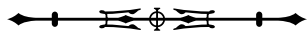


latitudes, aparecem impedimentos para a domesticação de animais, tais como mudanças climáticas e outras diferenças ambientais. Com isso, aquelas populações humanas que viviam no eixo leste-oeste do globo se favoreceram não só de animais domésticos, como também, ao longo do tempo, da imunidade referente às doenças que esses animais transmitiam, o que não teria sido o caso nas Américas, cuja população está disposta sobre o eixo norte-sul. Note-se que essas explicações manejam informações geográficas e históricas sobre o estado atual e antigo de populações humanas. São causas distantes, mobilizadas para explicar a conquista. $\bigcirc$ resultado do encontro entre espanhóis e ameríndios é decorrente de causas biogeográficas que produziram populações imunologicamente diferentes. Diamond (2009) não ignora por completo outros fatores proximais, relacionados à violência dos espanhóis e à estrutura social dos ameríndios em contato com europeus e escravos africanos, mas a ênfase que ele coloca nas epidemias evidencia que sua explicação biogeográfica relega essas outras causas a um patamar de menor importância.

Vários pontos do seu argumento sobre o poder devastador das epidemias têm sido severamente questionados. Por exemplo, as estimativas de 20 milhões de habitantes, para o México, antes da chegada dos espanhóis, apresentada por Diamond (2009) (citada acima), foram colocadas em questão mesmo antes da publicação de seu livro, por autores como Brooks (1993) e Assadourian (1989). Há outros autores que mostram que nem sempre as epidemias causaram o tamanho desastre que se supõe ter ocorrido no México e nos Andes, que a virgindade imunológica tende a desaparecer com a passagem do tempo, que o impacto populacional da doença não era um resultado inescapável (Livi-Bacci, 2007, 2011; Jones, 2003, 2016; Nash, 2014). Tivessem os conquistadores outros comportamentos ante as enfermidades dos ameríndios, o desfecho poderia ser diferente. A atribuição do colapso a uma única causa (epidemias) também foi posta em dúvida sob outros aspectos, desde problemas hermenêuticos na própria identificação das doenças, a partir de registros históricos, passando por críticas mais ideológicas em que a atribuição causal do desastre para as epidemias acaba, de uma forma ou de outra, implicando uma forma de racismo científico, intermediado por um determinismo imunológico. Há outras críticas de caráter mais filosófico, como a que aponta a improcedência de buscar regularidades na história (Calahan, 2005) ou aquela que indica o viés burguês do argumento (Correia, 2013), mas não trataremos desses problemas, uma vez que eles não estão diretamente relacionados às epidemias como causas suficientes, ou não, para o colapso demográfico que acometeu os ameríndios após a chegada de Colombo.

\section{O DEBATE INESGOTÁVEL}

Há um consenso entre historiadores e demógrafos históricos de que houve um colapso populacional dos ameríndios ao longo do século XVI. O que se discute, de forma intensa, são as dimensões e as causas dessa tragédia humana (Livi-Bacci, 2007; Henige, 2008; Storey, 2012; Jones, 2003, 2016). Por sua vez, a explicação em tela está intimamente associada ao tamanho da população do hemisfério ocidental antes do encontro com os europeus. No que se segue, indicaremos esse problema com um foco mais específico no que se conhece hoje como México (Tenochtitlán), embora haja trabalhos que apresentem e discutam a hecatombe em várias partes das Américas, incluindo os Altiplanos Andinos, a região conhecida como Mesoamérica, a Amazônia, os EUA e o Canadá.

Do ponto de vista demográfico, ao longo do século $X X$, houve um contraponto entre cenários 'baixistas', na categorização do demógrafo italiano Livi-Bacci (2007), que apresentavam as Américas como um continente esparsamente povoado, e cenários 'altistas' (Livi-Bacci, 2007) em que elas eram densamente habitadas (Denevan, 1992; Dobyns, 1966; Livi-Bacci, 2003, 2007, 2011; Jones, 2016). Assim, várias estimativas foram feitas ao longo do tempo. Ainda no século XVI, "Bartolomé de Las Casas acreditava que mais de 40 milhões de ameríndios morreram até o ano de 1560" (Denevan, 1992, p. 370, tradução nossa). Note-se

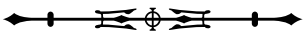


que Las Casas estaria estimando as mortes e não o número de habitantes das Américas pré-colombianas. A estimativa de Las Casas, naturalmente, não estava apoiada em qualquer método reconhecido pela historiografia mais recente. Para as primeiras décadas de 1900, vários autores sublinham que estudiosos como Alfred Kroeber, Angel Rosenblat e Julian Steward produziram estimativas de, no máximo, uma dezena de milhões de habitantes (Brooks, 1993; SánchezAlbornoz, 2003; Dobyns, 1966; Livi-Bacci, 2007; Jones, 2016). Todavia, ao longo do século $X X$, essa cifra vai ser inflacionada até se aproximar, e em alguns casos ultrapassar, cem milhões de pessoas, nos trabalhos de Woodrow Borah, Sherburne F. Cook, Henry Dobyns, George Lovell, Noble David Cook e William Denevan, entre outros (Denevan, 1992; Dobyns, 1966; Sánchez-Albornoz, 2003). Segundo Sánchez-Albornoz (2003), na década de 1960, Cook e Borah inauguraram uma nova especialidade científica: a demografia histórica americana. Cook e Borah são dois dos integrantes do que ficou conhecido como escola de Berkeley. Os trabalhos iniciais sobre as revisões demográficas foram realizados no México:

Cook e Borah estudaram, povo por povo, as visitas tributárias precoces que os oficiais espanhóis fizeram usando caciques como conhecedores das minúcias da sua tribo. Cada contagem encontrada nos arquivos revelou um passo desconhecido da evolução numérica do México central entre 1530 a 1610. O ápice [desse trabalho] foi alcançado quando ambos os autores conseguiram estimar o tamanho da população ameríndia na véspera da conquista. [...] Cook e Borah foram capazes de afirmar no final de sua reconstrução que a população indígena tinha desmoronado no centro do México de cerca de 25 milhões de habitantes em 1519 para cerca de 700.000 em 1625. Em pouco mais de um século, a maioria da população foi reduzida para cerca de 3 por cento do tamanho original, com quedas desiguais por região, altitude ou época. Depois da conquista, o coração do México foi despovoado. (Sánchez-Albornoz, 2003, p. 10-11, tradução nossa).

É importante enfatizar que os estudiosos da escola de Berkeley, depois de estudarem o México, investigaram outros locais em outros países, como a ilha de Espanhola e a Nova Granada, e os resultados, embora apoiados em uma base de fontes mais frágil do que as investigações sobre o colapso no México, eram parecidos. Trabalhos de outros pesquisadores sobre as regiões andinas, incluindo o atual Peru e a Bolívia, e várias regiões da chamada Mesoamérica, incluindo a penísula de Yucatán, onde se encontravam populações maias, atestaram também o desastre. Por toda a parte, parecia ter havido uma hecatombe populacional que se converteu em objeto de reflexão para a história mundial. E isso teria implicado uma mudança no foco causal:

Como explicação do desastre, as armas dos conquistadores foram relegadas para um segundo plano, pois pareciam muito simples para causar tanta mortalidade. Em vez disso, Cook e Borah admitiram a intempestiva irrupção das epidemias europeias. (Sánchez-Albornoz, 2003, p. 11, tradução nossa).

Para Cook e Borah, as epidemias teriam dizimado os nativos, pois estes não possuíam "[...] imunidade protetora prévia" (Sánchez-Albornoz, 2003, p. 11, tradução nossa; Cook, S.; Borah, 1977).

Há muitos trabalhos que apresentam estimativas populacionais para as Américas. William Denevan, professor de Geografia da Univeridade de WisconsinMadison, membro proeminente da escola de Berkeley, publicou muitos livros e artigos sobre o tema. Alguns dados de um de seus trabalhos nos dá um bom quadro, na década de 1990, das estimativas populacionais e das supostas causas do desastre humano no século XVI:

Sugeri recentemente um total de 53,9 milhões para o Novo Mundo [para época anterior à chegada de Colombo]. Isso se divide em 3,8 milhões para a América do Norte, 17,2 milhões para o México, 5,6 milhões para a América Central, 3,0 milhões para o Caribe, 15,7 milhões para os Andes e 8,6 milhões para a América do Sul. Estes números baseiam-se no meu julgamento quanto às estimativas tribais e regionais mais recentes. Aceitando uma margem de erro de cerca de $20 \%$, a população do Novo Mundo ficaria entre 43 e 65 milhões. Futuras revisões regionais provavelmente manterão o hemisfério total dentro desse intervalo. (Denevan, 1992, p. 370 , tradução nossa).

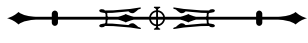


Denevan (1992) continua apresentando, então, o abrupto decréscimo no número de ameríndios ao longo do século XVI. Ele assinala que o declínio foi rápido e severo, e as epidemias, o principal assassino. Em muitas regiões, particularmente nas terras baixas tropicais, as populações caíram $90 \%$ ou mais no primeiro século após o contato. As populações ameríndias (estimadas) declinaram na ilha de Espanhola de 1 milhão, em 1492, para algumas centenas, 50 anos depois, o que corresponde a uma diminuição de mais de 99\%; no Peru, de 9 milhões, em 1520, a 670.000, em 1620 (decréscimo de 92\%); na bacia do México, de 1,6 milhões, em 1519, para 180.000, em 1607 (queda populacional de 89\%); e na América do Norte, de 3,8 milhões, em 1492, para 1 milhão, em 1800 (74\%). Um colapso geral de 53,9 milhões, em 1492, para 5,6 milhões, em 1650, equivale a uma redução de $89 \%$ (Denevan, 1992, p. 371).

Nicolás Sánchez-Albornoz é um historiador espanhol, professor emérito da Universidade de Nova York, com vários livros e artigos publicados em revistas especializadas em estudos de populações humanas. Em 2003, introduzindo um número especial do periódico Revista de Indias, ele chamou de "O debate inesgotável" a discussão sobre a causa (ou causas) do desastre demográfico que acometeu os ameríndios ao longo do século XVI. Alguns dos mais importantes especialistas da área publicaram artigos nesse número da revista. A leitura desses trabalhos revela muitas diferenças entre seus autores, desde as distintas estimativas populacionais pré-contato, passando pelo papel relativo ou (quase) absoluto das epidemias no debacle populacional, chegando na consideração, ou não, de determinantes sociais (Sánchez-Albornoz, 2003; LiviBacci, 2003; Cook, N., 2003; Malvido, 2003; Villamarín, Juan; Villamarín, Judith, 2003). Por exemplo, Elsa Malvido, investigadora do Instituto Nacional de Antropología e História do México, mostrou que uma sequência de epidemias que assolaram essa região no século XVI seria a causa primordial da retração demográfica dos ameríndios. Ela apresenta os anos de aparição, na Nova Espanha, de doenças como varíola (1521-1615), sarampo (1531-1563) e catapora (1538-1700), apontando a porcentagem de mortes na população virgem: 85 a 90 por cento para a varíola; 80 por cento para o sarampo; de 10 a 15 por cento para a catapora. Malvido (2003) ainda indica os grupos de idade mais afetados por essas doenças: todos, no caso da varíola; de zero a 62 anos, no caso do sarampo; e todos, de novo, no caso da catapora, oferecendo também informações sobre peste, papeiras e tosse convulsiva. Note-se que uma peculiaridade do fenômeno que estamos estudando é o fato de que muitas doenças afetaram populações de ameríndios (quase) ao mesmo tempo. Não é o caso de 'uma' epidemia que chega ao território de uma população imunologicamente virgem, mas de populações expostas a muitos patógenos diferentes, às vezes simultaneamente. Para Sánchez-Albornoz (2003, p. 15, tradução nossa),

Malvido expresa sua opinião de que se projetarmos
retrospectivamente a quantidade de sobreviventes
sobre o grau de mortalidade correspondente
para cada epidemia, a população alcançada
para o primeiro contato [entre ameríndios e
espanhóis], não seria muito distante daquela a
que Cook e Borah chegaram por outro caminho.

Na mesma direção, o historiador Noble David Cook, da Universidade Internacional da Flórida, publicou um artigo nesse número da Revista de Indias. David Cook resume seu trabalho, afirmando que a documentação divulgada em 2003 deu a ver que vários índios tainos, levados por Colombo para a Espanha para serem apresentados aos reis católicos, morreram de varíola em Cádiz, em 1493, antes de embaracarem na segunda expedição de Colombo para as Américas. Segundo Cook, N. (2003), devido às condições sanitárias predominantes eà aglomeração a bordo, a infecção pode afetar mais viajantes, que podem, assim, veicular doenças ao desembarcar. Para David Cook, a revelação desses documentos seria mais um pilar para a ideia de que epidemias seriam a causa primordial da dizimação de outras populações desde então (Sánchez-Albornoz, 2003; Cook, N., 2003).

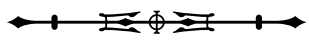


Ao nosso ver, é evidente que tanto Elsa Malvido quanto David Cook consideram que as epidemias são a causa do colapso das populações de ameríndios. Entretanto, estamos procurando argumentar que as epidemias respondem apenas pelas causas distantes, e que as causas próximas precisam ser apresentadas e consideradas.

Massimo Livi-Bacci, professor de demografia da Universidade de Florença e de história e economia de populações humanas, não concorda com a hipótese da epidemia em solo virgem. Em sua contribuição no referido número da Revista de Indias, ele ressalta que, quanto maior a estimativa populacional para o hemisfério ocidental antes da chegada dos europeus, maior força ganha a hipótese de que as doenças causadas por parasitos, sobretudo por vírus, são as responsáveis predominantes do fenômeno demográfico (Livi-Bacci, 2003, 2007). Como assinalado anteriormente, tais estimativas são obtidas a partir dos relatos de cronistas espanhóis e ameríndios, dos registros de tributos tanto dos governos locais como dos conquistadores, assim como de avaliações baseadas em arqueologia e geografia, além de projeções retrospectivas baseadas em taxas de despovoamento, observadas em um período posterior (Livi-Bacci, 2006). Assim, Livi-Bacci (2003, 2007) enfatiza que a discussão sobre os números é fundamental porque é a partir da estimativa do tamanho das populações ameríndias 'antes' do contato com os europeus, para mais ou para menos, que o poder das epidemias para a devastação populacional torna-se absoluto (monocausal) ou relativo. A historiografia tradicional reconhecia que a violência bélica dos espanhóis (a chamada Lenda Negra), a baixa na moral dos ameríndios que sobreviviam devido à perda de cônjuges, filhos, parentes e amigos, a exploração da força de trabalho dos ameríndios em plantações e nas minas de prata, a violência sexual dos espanhóis contra as ameríndias, tributos demasiado altos, a escassez nutricional poderiam estar relacionadas a muitas mortes, talvez dezenas ou mesmo centenas de milhares. Mas, na medida em que as cifras se multiplicam para muitas dezenas de milhões (lembremos que a estimativa de Cook e Borah é de 25 milhões apenas para o México), a hipótese de que as epidemias são as maiores responsáveis pela tragédia ganha muita força, pois, segundo Livi-Bacci (2003, 2006, 2007, 2011), o poder das outras causas alegadas, intermediada por ações humanas, é praticamente desprezível ante a enorme fatalidade das doenças. Todavia, assim como outros autores (Brooks, 1993; Henige, 2008; Jones, 2003, 2016; Storey, 2012; Nash, 2014), Livi-Bacci (2003, 2006, 2007, 2011) não concorda que as epidemias sozinhas possam explicar o colapso populacional. O autor também não aceita números populacionais tão altos, como os de Cook e Borah (Sánchez-Albornoz, 2003; Livi-Bacci, 2003, 2006, 2007, 2011).

As estimativas para o hemisfério ocidental, incluindo o México, antes da chegada dos europeus, que asseguram o poder das epidemias como causa do colapso, receberam várias críticas, mesmo antes da publicação de um livro como "Armas, germes e aço", que é de 1997 (Zambardino, 1980; Assadourian, 1989; Brooks, 1993). No artigo intitulado "Revising the conquest of Mexico: smallpox, sources, and populations", publicado em 1992, Francis Brooks sintetiza o problema da seguinte forma:

\begin{abstract}
Se a população em 1519 fosse cinco vezes maior do que se pensava ser, então nossas percepções da força e complexidade da política Asteca deveriam ser fundamentalmente reestruturadas também. Mais crucial, no entanto, é a dimensão do colapso demográfico revelado na proporção entre os números, de cerca de 25 milhões em 1519 e cerca de 1 milhão em 1600. Uma queda de $96 \%$ em uma população tão grande era, literalmente, desconhecida e, se for verdade, é única na história do mundo. Nenhum massacre meramente humano poderia explicar tal catástrofe, mesmo permitindo que o assassinato fosse estimulado por anomia e perda da vontade de viver por parte das vítimas. Alguma visitação ou aflição de Deus ou da natureza deve ser invocada para dar conta dessa mortalidade total. Varíola, entendida por Macaulay, como "o mais terrível de todos os ministros da morte", parece se encaixar no caso precisamente. Se a varíola atacou grandes grupos de povos indígenas, que estavam despreparados e não imunes, somos levados a esperar que milhões deles tenham morrido. (Brooks, 1993, p. 1, tradução nossa).
\end{abstract}

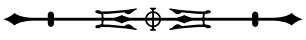


Brooks (1993) é extremamente crítico a essa estimativa de 25 milhões de habitantes no México, em 1518/1519, antes do contato com os espanhóis. Ele interpõe várias questões sobre os métodos adotados por Cook e Borah para chegar a essas altas cifras, além de questionar a identificação de doenças como a varíola, entre os astecas, assim como os anos exatos das primeiras epidemias. Ele explora bastante o texto de Zambardino (1980), que problematiza matematicamente a forma como Cook e Borah trabalharam, e oferece estimativas bem mais modestas tanto para o México quanto para outras partes do hemisfério ocidental. Para Brooks (1993), o que se alcançou como resultado direto dos números de Borah e Cook foi o estabelecimento dos conceitos de populações em solos virgens e da epidemiologia de doenças infecciosas em populações não imunes. Mas esses novos conceitos não respondem pela tragédia em tela:

Isso que deve ser questionado. Em contraste, as conclusões dos antropólogos físicos, derivadas da capacidade de suporte da tecnologia agrícola disponível, ainda apontam teimosamente para um número total, para o México em 1500, na faixa entre 5 a 10 milhões. (Brooks, 1993, p. 4-5, tradução nossa).

Ainda anteriormente, Assadourian (1989, p. 420, tradução nossa) também contestou as cifras dos autores da escola de Berkeley e, embora não negasse o poder das doenças em ceifar enormes cifras de vidas ameríndias, afirmou que há outras causas em foco, bem exemplificada pelas "[...] dez pragas trabalhosas com que Deus castigou essa terra", que Frei Toribio de Motolinía, em torno de 1541, apontou como causas da despopulação, entre elas as guerras, a fome, os tributos impostos aos ameríndios, o trabalho nas minas de ouro e na edificação da cidade do México, além, é claro, de epidemias. Livi-Bacci (2007) também aponta Motolinía como o cronista que indicou corretamente as causas do colapso demográfico, embora não tenha estimado o peso das epidemias ante outras formas de destruição (Assadourian, 1989).
Segundo Livi-Bacci (2007) e Jones (2016), se aceita nos círculos especializados estimativas mais moderadas do que a dos integrantes da escola de Berkeley, algo em torno de cinquenta milhões de habitantes, talvez um pouco menos ou um pouco mais (Koch et al., 2019). Entretanto, mesmo com essa cifra mais modesta, o problema continua sendo como explicar o abrupto decréscimo das populações ameríndias, evidente pela leitura das fontes em jogo, pois as causas decorrentes de ações humanas seriam muito insuficientes para justificar tamanho despovoamento. Assim, mesmo que, por exemplo, a população do México, antes da chegada de Cortes fosse de dez milhões, e não de vinte e cinco milhões (ou vinte milhões, como sugere Diamond), a perda seria ainda de cerca de $90 \%$, pois se sabe com bastante segurança que não havia mais do que um milhão de mexicanos ao fim do século XVI (Cook, S.; Borah, 1977). Esse índice de mortalidade ainda seria um dos mais dramáticos da história.

Assim, o que está em jogo não é se as epidemias ocorreram ou não, ou se seu efeito foi devastador ou não. $O$ que se discute é o quanto as epidemias podem ser apontadas como a causa suficiente do colapso ou se elas devem ser complementadas por causas de origem social, como violência, fome e abatimento moral e psicológico. Autores como Diamond (2009), Malvido (2003) e Cook, N. (2003) aceitam o poder quase absoluto das epidemias e, embora reconheçam outros fatores causais (proximais), não os consideram suficientes nem necessários para explicar o colapso. As epidemias explicam o desastre populacional em um ambiente em que os índios seriam imunologicamente virgens aos patógenos trazidos pelos espanhóis. Entretanto, autores como Brooks, Assadourian, Livi-Bacci, o próprio Sánchez-Albornoz postulam que causas próximas devem ser conjugadas com as epidemias, sob o risco de naturalizarmos um desastre histórico que nada teve de necessário e inevitável. Por exemplo, Livi-Bacci (2006) aponta que houve epidemias que não se traduziram em tragédia populacional, como cerca de trinta missões jesuíticas no Paraguai

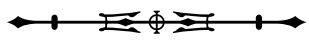


que tutelaram, por motivos diversos, o povo Guarani. Nesse caso, houve aumento populacional, apesar das epidemias, das guerras, da fome e de outros fatores de estresse: "Desde a década de 1640 - quando a missão jesuíta do Paraguai alcançou a estabilidade territorial até o início da década de 1730, a população Guarani, guiada pelos padres jesuítas, aumentou de 40.000 para mais de 140.000" (Livi-Bacci, 2006, p. 219, tradução nossa). $\bigcirc$ que estamos querendo indicar é que a forma da colonização, violenta ou mais humana, tem um papel preponderante na capacidade das populações ameríndias de suportar epidemias.

Há muitas outras considerações a serem feitas ao suposto poder suficiente das doenças. Livi-Bacci apresenta as bases darwinistas (evolutivas) da hipótese da epidemia em solo virgem, e considera que "o efeito catastrófico das epidemias tende a se atenuar com o tempo, à medida que se completam os processos graduais de adaptação e seleção" (Livi-Bacci, 2003, p. 41, tradução nossa). Assim, os sobreviventes expostos de uma epidemia transmitem sua imunidade para seus filhos, tornando a população, ao longo do tempo, resistente ao patógeno. Para Livi-Bacci (2003, p. 41, tradução nossa), o retrocesso populacional tem uma série de causas complementares, que devem ser compreendidas como causas próximas do desastre:

Duas delas merecem atenção especial, uma vez que - entre outras coisas - afetam a reprodutividade e, consequentemente, a capacidade de reagir a crises e episódios de maior mortalidade. Eu as definirei como o "efeito de deslocamento" e o "efeito de subtração", o deslocamento social e a subtração do patrimônio reprodutivo. $\bigcirc$ efeito de deslocamento - repartimiento y encomienda; trabalhar nas minas; a concentração nas aldeias; migrações forçadas; a subtração de terras e consequente eliminação de culturas tradicionais para criar grandes plantações ou pastagens - produziu efeitos de todos os tipos e alterou o equilíbrio das comunidades tradicionais. [...] De um ponto de vista puramente demográfico, pode-se pensar que o deslocamento contribui para a mortalidade: a migração pode levar à fome, o trabalho forçado em campos ou minas pode enfraquecer a população, tornando-a mais vulnerável a doenças endógenas e importadas; a concentração nas aldeias, contribui para a disseminação de epidemias mais rapidamente. [...] Através do efeito de "subtração", as mulheres são mais ou menos expulsas do patrimônio reprodutivo indígena para entrar no patrimônio reprodutivo dos colonizadores, produzindo uma redução na taxa de natalidade [...]

Para a narrativa que estamos desenvolvendo, esses fatores proximais devem compor a equação que pretende explicar a conquista e o colapso populacional. A desestruturação da força de trabalho e da capacidade reprodutiva dessas populações sugere um quadro de extrema miséria material, associada a graus elevados de má nutrição e estresse. Até que ponto as epidemias causaram essa situação ou foram favorecidas por ela é a questão que foi aberta depois que a hipótese da epidemia em solo virgem se achou instituída. No mesmo ano de 2003, em que "O debate inesgotável" foi discutido na série de trabalhos introduzidos por Nicolás Sánchez-Albornoz, na Revista de Indias, independentemente, David S. Jones, membro do Departamento de Psiquiatria do Hospital McLean e do Hospital Geral de Massachusetts, publicou o artigo "Virgin soils revisited", no qual discutia os limites da hipótese Crosby-MacNeill, de pontos de vista biológico (imunológico), demográfico e sociológico. Impossível sintetizar a riqueza crítica do texto de Jones. Focaremos em alguns aspectos que nos chamaram muita atenção, inclusive porque eles serão retomados em artigo do mesmo autor, publicado treze anos mais tarde. Por exemplo, para Jones (2003, p. 104, tradução nossa), é preciso qualificar a ideia de que os ameríndios eram imunologicamente virgens às doenças espanholas:

\footnotetext{
Os índios americanos não tinham genes específicos que tornaram europeus e africanos, depois de gerações de seleção natural, mais resistentes à varíola e à tuberculose? Eles não tinham anticorpos que suas contrapartes da Eurásia adquiriam durante a infância de exposição a infecções endêmicas? Foram seus sistemas imunológicos comprometidos pela desnutrição, exaustão e estresse criado pela colonização europeia? Essas diferentes questões, obscurecidas dentro da simples alegação de não
}

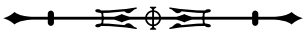


imunidade, têm implicações muito diferentes para a nossa compreensão do que foi responsável por esta catástrofe demográfica.

O problema para Jones, tal qual colocado também por Livi-Bacci, Sánchez-Albornoz, Assadourian, entre outros, é que não se pode e nem se deve, em termos filosóficos e morais, tentar explicar o fenômeno demográfico apelando 'apenas' para causas distantes, sob o risco de obscurecer outras causas que merecem atenção. Segundo Jones (2003), um livro como "Armas, germes e aço" subestima as causas próximas, quando, por exemplo, afirma que os índios americanos não tinham resistência imunológica nem genética a doenças:

Isso não faz sentido. Índios, como todos os seres humanos - e todos os vertebrados possuem elaborados sistemas imunológicos e podem montar poderosas defesas contra vírus, bactérias, fungos e parasitas, mesmo em uma primeira exposição. Ninguém é imunologicamente indefeso. Haveria alguma coisa que deixaria o sistema imunológico ameríndio mais sutilmente deficiente? Muitas afirmações de "não imunidade" dependem da alegação de que o isolamento ameríndio das doenças, que os deixaram livres no paraíso das Américas, enfraqueceu seu sistema imunológico. Mas os arqueólogos já mostraram que muitas doenças existiam nas Américas antes dos europeus chegarem, incluindo tuberculose, treponematose, pneumonia, osteomielite, febre tifoide, shigella, salmonela, leishmaniose, doença de Chagas, toxoplasmose, amebíase, giardíase, tinha, blastomicose e infestações com vermes, lombrigas e ancilostomídeos. Os sistemas imunológicos dos ameríndios indianos tinham tido exercício pleno. (Jones, 2003, p. 10, tradução nossa).

Note-se que Jones (2003) enfatiza a diferença entre imunidade genética (inata) e imunidade adquirida (adaptativa), assim como entre resposta imune celular e humoral, que precisariam ser melhor conhecidas para poder dar sustentação à hipótese da epidemia em solo virgem. $\bigcirc$ autor também argumenta que estudos atuais não corroboraram a hipótese de que povos nativos sejam particularmente mais suscetíveis a novas doenças (Crosby, 1976; Jones, 2003, 2016). Todavia, a questão central de Jones (2003) não é meramente imunológica, mas sociológica, ideológica e política. Segundo ele, Crosby já havia atentado para isso, recuando da própria hipótese que contribuiu para criar: "Crosby, depois de considerar o mecanismo do solo virgem, concluiu que as altas taxas de mortalidade refletiam as terríveis condições de vida dos ameríndios, e não uma inerente falta de imunidade inata ou adaptativa" (Jones, 2003, p. 11, tradução nossa). Jones (2003) articula um argumento que, a meu ver, parece fatal para hipótese da epidemia em solo virgem como explicação monocausal do declínio demográfico. Ele defende de forma aguda que as narrativas que contamos sobre o passado têm consequências sobre como lidamos com epidemias hoje. Elas modelam nosso pensamento sobre as inequalidades de saúde para os ameríndios, e também para outras populações humanas vulneráveis hoje:

[...] bem poderia ser que as epidemias entre os índios americanos, apesar de sua severidade incomum, tenham sido causadas pelas mesmas forças da pobreza, desnutrição, estresse social, deslocamento, desigualdade econômica e vulnerabilidade ambiental que favoreceram epidemias em todos os outros tempos e lugares. (Jones, 2003, p. 11, tradução nossa).

Jones (2003) não está questionando a importância das doenças epidêmicas, nem a existência de mecanismos genéticos de resistência e suscetibilidade a doenças. ○ que está em questão é a contribuição relativa das causas socioculturais, de um lado, e das causas genéticoimunológicas, do outro. E, desse ponto de vista, ele critica a hipótese da epidemia em solo virgem por desconsiderar as causas sociais, próximas, a interação entre os ameríndios nativos e os espanhóis. Para Jones (2003), o colapso demográfico de populações extintas não é apenas matéria acadêmica, pois nossa interpretação do que ocasionou esse desastre influencia a forma como interpretamos a importância das epidemias hoje, entre ameríndios e outras populações socialmente fragilizadas. Ao considerar as epidemias como a causa única da estrondosa ruína dessas populações no passado,

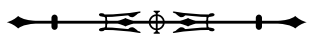


tendemos a fazer o mesmo para as populações atuais, não só entendendo as consequências das epidemias como uma fatalidade, via um determinismo imunológico cientificamente discutível, materializado pela hipótese da epidemia em solo virgem, mas também nos eximindo de procurar soluções sociais e políticas, ou seja, buscar mudanças em fatores socioambientais que são relevantes como causas próximas para situações, muitas vezes, indigentes dessas populações (Jones, 2003):

O determinismo imunológico tem sido usado como argumento contra supostos fracassos da cultura indígena americana. Os historiadores há muito acreditavam nas conquistas fáceis de Hernan Cortes e Pizarro, devidas às tecnologias, estratégias e lideranças militares europeias superiores. Em tais histórias tradicionais, astecas e incas, ignorantes e ingênuos, nunca tiveram uma chance. Mas, enfatizando o poder das epidemias, os historiadores podem fazer uma afirmação oposta. Os astecas e incas, ambos poderosos e partes de sociedades sofisticadas, teriam sido adversários formidáveis, caso eles não fossem devastados pelo poder irresistível da varíola. Como Karen Kupperman argumenta: "Foram realmente as doenças europeias e não a tecnologia europeia superior que derrotaram os índios nos primeiros anos". Mas enfatizando a falta de imunidade para desviar a culpa das culturas indígenas americanas e instituições, esses teóricos bem-intencionados transferem a responsabilidade aos corpos indígenas americanos. (Jones, 2003, p. 713, tradução nossa).

Em 2016, David Jones publicou um outro trabalho sobre o tema das epidemias como causa do colapso populacional dos ameríndios. Ele continua contestando a teoria da epidemia em solo virgem como explicação monocausal para a conquista espanhola. Assim como Henige (2008) e Livi-Bacci (2007), Jones (2016) aponta que não há evidências inequívocas de que doenças, que não deixam marcas nos ossos de suas vítimas (caso da própria varíola), tenham sido responsáveis únicas pela devastação. Ele também contesta a ideia de que os ameríndios viviam, antes da chegada dos europeus, em um ambiente livre de doenças, afimando que, a despeito de décadas de estudo, os pesquisadores não encontraram evidência de dramáticas diferenças na suscetibilidade racial à tuberculose, à varíola, ao sarampo e a outros patógenos proeminentes:

\begin{abstract}
Alguns escritores descontam as diferenças genéticas e argumentam, em vez disso, que a principal diferença foi a falta de imunidade adquirida, mas isto é principalmente relevante para um pequeno número de patogénios virais (por exemplo, varíola, sarampo). Muitos outros vírus e patógenos bacterianos podem infectar e reinfectar pessoas repetidamente. Qual a parcela de mortalidade foi causada por doenças como a varíola, para a qual a imunidade adquirida é relevante? Isso não é conhecido e provavelmente não é cognoscível. Além desse fator, é possível que a introdução simultânea de novos patógenos possa ter aumentado a mortalidade por causa dos efeitos sinérgicos da doença generalizada e da subsistência interrompida. (Jones, 2016, p. 421, tradução nossa).
\end{abstract}

O que nos chama a atenção é que Jones (2016) procura conjugar o poder certamente brutal das epidemias com a 'subsistência interrompida'. Isso parece indicar que as doenças, para chegarem a esse poder devastador no nível das populações, precisaram ser favorecidas por condições ambientais, aqui traduzidas por ações humanas, intencionais ou não:

[...] pode ser que não sejam necessários mecanismos especiais para explicar os destinos dos ameríndios. Os melhores registros de mortalidade extrema vêm de lugares expostos a colonizações agressivas (por exemplo, Nova Espanha [incluindo o México]). Se a mortalidade realmente ocorreu ao longo de um século, então há muitas forças, até mesmo mundanas, que poderiam ter erodido as populações. Muitas sociedades ameríndias encontravam-se em estado nutricional marginal antes do contato. Desnutrição na linha de base pode ter deixado os índios americanos vulneráveis, no início, às doenças europeias. Quando as condições de colonização interromperam a subsistência, a situação só piorou. Qualquer fator que cause estresse mental ou físico - como deslocamento, guerra, seca, destruição de cultivos, esgotamento do solo, excesso de trabalho, escravidão, desnutrição, caos social e econômico - pode aumentar a suscetibilidade à doença. Desastres naturais, incluindo secas, fracassos de colheitas, terremotos, vulcões e furacões, contribuíram para o sofrimento. (Jones, 2016, p. 421, tradução nossa).

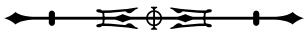


Essa conjugação de causas biológicas distantes, como as epidemias, e causas sociais próximas, como escravidão, fome, excesso de tributos, desalento moral (entre outras), pode ter criado o cenário que resultou no colapso demográfico do século XVI. Talvez também esteja relacionado com os limites agroecológicos das sociedades ameríndias, que não dominavam o aço e as técnicas de produção de alimentos dependentes do arado com tração animal, capazes de sustentar grandes populações por muitas gerações (Brooks, 1993; Mann, 2007).

Embora tenhamos tomado as categorias de causas distantes e causas próximas da medicina evolutiva, ela própria, até agora, não interpretou o fenômeno que nos prende aqui, com excessão da breve referência de Stearns e Medzhitov (2016), apresentada anteriormente. Isso pode se relacionar ao fato de que a medicina evolutiva está mais preocupada com questões que afligem as populações humanas vivas, e não com as extintas. Todavia, autores como Jones, Livi-Bacci e Henige atribuem uma importância política muito atual à forma como interpretamos o fenômenos do colapso dos ameríndios ao longo do século XVI. E isso tem implicações na forma como compreendemos as doenças hoje. Nas palavras de Jones (2016, p. 413, tradução nossa): "As narrativas que os historiadores contam sobre a história demográfica influencia como nós pensamos sobre as desigualdades hoje, e isso pode ter uma profunda consequência para a saúde da população e política de saúde". Ou seja, se pensarmos que epidemias são as causas únicas do colapso, tenderemos a compreender as doenças hoje apenas como matéria de parasitos e anticorpos, pouco ou nada relacionadas a condições sociais, que deveriam também ser investigadas e combatidas.

Livi-Bacci (2007) talvez seja mais explícito na importância de conjugar causas biológicas com causas sociais. Seu livro "Conquista: a destruição dos índios americanos" vai muito além do colapso populacional dos ameríndios no século XVI, buscando as implicações desse fenômeno demográfico nas populações dos séculos seguintes, chegando mesmo a tempos mais atuais. Ele aponta, com muita clareza, uma mudança nas formas de compreender o colapso relacionado ao encontro entre ameríndios e europeus, e defende que, muitas vezes, a hipótese da epidemia em solo virgem foi usada com viés político. Do ponto de vista epidemiológico, Livi-Bacci (2007, p. 57) foca muitos dos seus estudos na varíola, porque ela "[...] foi a patologia mais violenta e mais letal pelos seus efeitos, de longe mais desatrosos do que os das outras novas doenças na América"; e porque as considerações epidemiológicas referentes à varíola "[...] podem estender-se a outras patologias, que partilham muitas das suas características" (Livi-Bacci, 2007, p. 57). Ele salienta vários aspectos biológicos da varíola: como o fato de ela ser definida como uma "patologia de rebanho", uma doença de multidão, assim como o sarampo e a escarlatina; que a varíola se transmite por via aérea; que há um período de latência; que a infecciosidade é muito alta e aumenta devido às condições de alta densidade populacional. Acompanhemos um modelo teórico desenvolvido por Livi-Bacci (2007) para infecciosidade da varíola, que, ao ser criticado por ele mesmo, irá manifestar a importância de conjugar casuas próximas e causas distantes:

Considere-se uma aldeia indígena, de 1.000 habitantes, todos não imunes; suponhamos que a varíola contagie toda a população [...] Se a mortalidade média entre os contagiados for de $40 \%$, teremos 400 mortos e 600 sobreviventes; estes, tendo contraído a varíola e tendo sobrevivido, são agora imunes. (Livi-Bacci, 2007, p. 62)

Ele segue esse raciocínio matemático ao longo de algumas gerações dessa aldeia hipotética, afetadas de quinze em quinze anos pela doença, para concluir: "Trinta anos depois da primeira chegada da varíola, a população estaria reduzida a pouco mais de quatro décimos da quantidade inicial e isto pode, sem dúvida, definir-se como uma verdadeira catástrofe" (Livi-Bacci, 2007, p. 63). Mas, para Livi-Bacci (2007, p. 63), esse exemplo é extremo principalmente por três razões: 
A primeira é que, à chegada da epidemia, nem todos os indivíduos suscetíveis de contágio são efetivamente contagiados; o acaso, a natureza (há indivíduos resistentes à infecção), ou a separação e a distância das fontes de contágio façam com que haja sempre uma proporção significativa de não contagiados. Além disso é provável que esta proporção aumente com o tempo, porque se aprende a reconhecer os sintomas e evitar o contato. A segunda razão é que a mortalidade dos contagiados, para qual conjecturamos o nível máximo de $40 \%$, pode ser mais baixa, e seja como for, tende a diminuir após a primeira epidemia. Para isso contribuem dois grupos de fatores, biológicos e sociais: há um processo de seleção que faz com que, entre os que se curam, haja indivíduos naturalmente mais resistentes ao vírus que transmitem estas características aos seus filhos. Mas há também uma aprendizagem social, segundo a qual, após as primeiras epidemias, os doentes não são abandonados a si próprios, sem comida, sem água, sem sustento, pelo que aumenta a taxa de cura. [...] A terceira razão invoca uma lei quase universal, verificada em inúmeras situações históricas: depois de uma epidemia há um "ressalto" demográfico, isto é, um significativo acréscimo dos nascimentos em relação às mortes. Os primeiros aumentam porque aumentam as uniões entre sobreviventes dos casais desfeitos por uma morte; as outras diminuem porque a epidemia dizimou sobretudo os mais vulneráveis, as crianças e os idosos, pelo que restam principalmente pessoas com risco de morte menor que a média. Em suma, a população não fica estacionária após a epidemia (como no exemplo supracitado).

A segunda razão de Livi-Bacci para considerar o exemplo inicial extremo é justamente a articulação de causas biológicas e sociais contribuindo para certo resultado demográfico, não inevitável, do encontro dos espanhóis com os ameríndios. Como se depreende, melhores condições de vida (água potável, comida, diminuição de tributos, alívio da carga de trabalho) e ajuda humanitária poderiam ter contribuído para uma mortalidade menor. Nesse âmbito, Jones (2016) assinala que pensar que as epidemias são causas suficientes para explicar o colapso impacta na forma como entendemos as doenças hoje, pois tendemos, então, a desprezar o quanto ações humanas podem potencializar ou amenizar a transmissão e o impacto das doenças. Jones (2016) nos chama a atenção de que os historiadores têm responsabilidade política, por conta de suas interpretações do passado, pois elas afetam a forma como interpretamos o presente, as doenças no presente:

\begin{abstract}
Acadêmicos que desejam navegar no terreno contestado e cobrado da saúde indígena, passado ou presente, têm a obrigação de fazê-lo com cautela e cuidado. Eles devem pensar criticamente sobre as evidências que eles geram e sustentam. Tais evidências são crívies? São representativas? Podem ser suportadas por outros exemplos? Eles [os acadêmicos] devem pensar cuidadosamente sobre como constroem seus argumentos, com uma consciência ativa do papel da especulação e da retórica em seus escritos. E eles devem estar atentos aos efeitos que seus argumentos podem ter. Mesmo uma alegação aparentemente simples sobre uma epidemia remota pode ter consequências sobre como os leitores entenderão questões de significado, moralidade e responsabilidade. E se os estudiosos se concentram em causas biológicas ou genéticas, naturalizam as disparidades. Embora tal naturalização possa reduzir a vergonha e o estigma, comparados com explicações comportamentais ou culturais, isso pode ser problemático, pois acaba ocultando a agência social nas histórias que contam sobre o passado. E então, hoje, corremos o risco de cometer o mesmo erro em nossa compreensão das desigualdades em saúde. (Jones, 2016, p. 426, tradução nossa).
\end{abstract}

\section{CONSIDERAÇÕES FINAIS}

Apesar de todas as ressalvas sobre o poder causal insuficientes das epidemias, que aos olhos da nossa própria narrativa parece justo e incontornável, o debate continua vivo, inesgotável. Em 2017, no artigo "The one health concept - the Aztec empire and beyond" (Puente; Calva, 2017), dois cientistas mexicanos investigaram material biológico de ameríndios da época da conquista. Eles encontraram uma bactéria, Salmonella enterica, que 'pode' explicar melhor uma epidemia denominada pelos astecas como cocoliztli. Deixando de lado a enorme dificuldade de identificar, com segurança, quaisquer doenças por sintomas descritos por cronistas do século XVI (Brooks, 1993; Livi-Bacci, 2007), os autores argumentam que infecções por essa espécie de Salmonella (encontrada na polpa dos dentes de ameríndios astecas) são condizentes com os sintomas que caracteriza o cocoliztli no registro histórico.

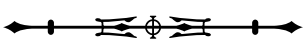


Segundo eles, varíola e sarampo raramente seriam tão populacionalmente fatais (mas pense se as populações que essas doenças afetam estivessem fragilizadas por guerras, pobreza, fome, subtração da força de trabalho). Puente e Calva (2017) não fazem mais referências a circunstâncias sociais ou políticas, para além de dizer que "Batalhas, secas, fome foram eventos que dizimaram a população [do México], mas as doenças infecciosas foram a maior causa na dramática mudança demográfica que ocorreu então" (Puente; Calva, 2017, p. 1, tradução nossa).

Trabalhos ainda mais recentes trazem novas descobertas sobre epidemias que se abateram sobre o hemisfério americano, sem, contudo, levar em consideração as relações entre causas próximas e causas distantes. Vågene et al. (2018) publicaram um artigo na revista Nature Ecology \& Evolution, propondo que a mesma bactéria anteriormente referida, Salmonella (mas agora especificada como Salmonella enterica subsp. enterica serovar Paratyphi C), seja uma forte candidata à causa do declínio da população asteca durante o surto epidêmico, de 1545, de cocoliztli em TeposcolulaYucundaa, no México, que teria chegado a matar cerca de 800.000 pessoas (Vågene et al., 2018; Acuña-Soto et al., 2000). Esses autores também trabalharam com dentes, e usando técnicas moleculares sofisticadas, foram capazes de demonstrar que a bactéria encontrada nos dentes 'não' era uma contaminação do solo de onde os corpos foram desenterrados, podendo responder por esse obsceno número de mortes. Os resultados apresentados contribuem para enriquecer o quadro epidemiológico do México no século XVI (Vågene et al., 2018), mas não levam em consideração possíveis causas próximas do colapso.

Em 2019, uma hipótese surpreendente que envolvia as estimativas populacionais do hemisfério ocidental e a força das epidemias veio à luz: as epidemias relacionadas à conquista espanhola teriam sido responsáveis pelo que os climatologistas chamam de 'pequena idade do gelo', um resfriamento no planeta que começou a ocorrer logo ao fim da Idade Média e se estendeu até o início da
Revolução Industrial. Segundo os autores do trabalho, as epidemias levaram ao abandono dos campos de cultivo das populações ameríndias, que foram afetadas por sucessão ecológica secundária, trazendo de volta à paisagem florestas com grandes árvores. Tais florestas fixariam gás carbônico $\left(\mathrm{CO}_{2}\right)$, subtraindo-o da atmosfera, o que explicaria o resfriamento do planeta (Koch et al., 2019). Os autores, todavia, ao considerarem as causas do colapso, estabeceram um foco quase exclusivo nas epidemias. Curiosamente, eles citam trabalhos como os de Livi-Bacci (2007) e Jones (2003), embora não haja uma palavra sequer sobre as críticas desses autores ao paradigma epidemiológico como causa do desastre populacional. Percebe-se que essas considerações não invalidam o impacto do colapso demográfico, que ocorreu para além das causas em disputa, pois o que está em jogo no trabalho é a correlação entre a destruição dos campos de cultivo e a diminuição da temperatura da Terra (Koch et al., 2019).

Não é difícil de imaginar como autores como Jones e Livi-Bacci reagiriam a esses trabalhos. Que a desnutrição, por exemplo, possa favorecer a disseminação de Samolnella não é uma hipótese absurda. Também não é improvável que a extenuação da força de trabalho, a apropriação da capacidade reprodutiva das populações dos astecas, entre outros fatores sociais, também pudessem pavimentar a falta de resistência a essa bactéria. A responsabilidade que nos cabe sempre é de não desconsiderar que ambas as causas, próximas e distantes, são conjuntamente necessárias e individualmente insuficientes para explicar qualquer fenômeno biológico, como enfatizou Mayr e como propõe a medicina evolutiva. Como nos chama a atenção Massimo Livi-Bacci, nas últimas linhas de seu livro "Conquista: a destruição dos índios americanos": "A catástrofe, portanto, não foi um destino obrigatório, antes efeito da interação entre fatores naturais e comportamentos humanos e sociais, cujo resultado não estava determinado à partida" (Livi-Bacci, 2007, p. 237).

O exercício de conjugar as causas próximas com as causas distantes demanda reconhecer que um processo 
histórico, como a conquista espanhola, não pode ser compreendido ou explicado até que se tenha um quadro consensuado do peso de cada fator para o desfecho desastroso. Considerando que nenhum entendimento da derrocada dos ameríndios pode ser sugerido sem a participação das epidemias, atestadas em inúmeras fontes históricas, seu peso deve ser cuidadosamente examinado à luz de trabalhos que têm nos ensinado sobre a estrutura social e reprodutiva dos povos culturalmente heterogêneos que habitavam as Américas do Sul, Central e do Norte. Tais interpretações indicam que devemos ter cuidado para não oferecer, hoje, oportunidades ambientais e socioculturais para que doenças possam tornar-se epidêmicas e até pandêmicas, principalmente entre populações mais socialmente fragilizadas.

\section{REFERÊNCIAS}

ACUÑA-SOTO, Rodolfo; CALDERÓN ROMERO, Leticia; MAGUIRE, James $\mathrm{H}$. Large epidemics of hemorrhagic fevers in Mexico 1545-1815. The American Journal of Tropical Medicine and Hygiene, Cleveland, v. 62, n. 6, p. 733-739, June 2000. DOI: https://doi.org/10.4269/ajtmh.2000.62.733.

ALCOCK, Joe. Emergence of evolutionary medicine: publication trends from 1991-2010. Journal of Evolutionary Medicine, Honnelles, v. 1, p. 1-12, 2012. DOI: https://doi.org/10.4303/jem/235572.

ASSADOURIAN, Carlos Sempat. La despoblación indígena en Perú y Nueva España durante el siglo XVI y la formación de la economía colonial. Historia de Mexicana, Ciudad de Mexico, v. 38, n. 3, p. 419-453, enero/marzo 1989.

BORAH, Woodrow. America como modelo? El impacto demografico de la expanción europea sobre el mundo no europeu. Cuadernos Americanos, Ciudad de México, n. 6, p. 175-185, nov./dic. 1962.

BROOKS, Francis J. Revising the conquest of Mexico: smallpox, sources, and populations. The Journal of Interdisciplinary History, Cambridge, v. 24, n. 1, p. 1-29, Summer 1993. DOI: https://doi. org/10.2307/205099.

CALAHAN, Gene. The Diamond fallacy. Mises Institute, Alabama, p. 1-9, Mar. 2005. Disponível em: https://mises.org/ibrary/diamondfallacy. Acesso em: 23 jan. 2019.

CAPONI, Gustavo. Contribución a una historia de la distinción próximo-remoto. Revista Brasileira de História da Ciência, Rio de Janeiro, v. 7, n. 1, p. 16-31, jan./jun. 2014.
CAPONI, Gustavo. La segunda agenda darwiniana: contribución preliminar a una historia del programa adaptacionista. México: Centro de Estudios Filosóficos, Políticos y Sociales Vicente Lombardo Toledano, 2011.

COOK, Noble David. ¿Una primera epidemia americana de viruela en 1493? Revista de Indias, Madrid, v. 63, n. 227, p. 49-64, abr. 2003. DOI: https://doi.org/10.3989/revindias.2003. i227.551.

COOK, Sherburne F.; BORAH, Woodrow. Ensayos sobre historia de la población: México y el Caribe. Ciudad de Mexico: Siglo XXI, 1977. v. 1.

CORREIA, David. F**k Jared Diamond. Capitalism Nature Socialism, Abingdon-on-Thames, v. 24, n. 4, p. 1-6, Oct. 2013. DOI: https://doi.org/10.1080/10455752.2013.846490.

CROSBY, Alfred W. Virgin soil epidemics as a factor in the aboriginal depopulation in America. The William and Mary Quarterly, Virginia, v. 33, n. 2, p. 289-299, Apr. 1976. DOI: https://doi.org/10.2307/1922166.

DENEVAN, William M. The pristine myth: the landscape of the Americas in 1492. Annals of the Association of American Geographers, Milton Park, v. 82, n. 3, p. 369-385, Sept. 1992. DOI: https://doi.org/10.1111/j.1467-8306.1992.tb01965.x.

DIAMOND, Jared. Armas, germes e aço. Tradução de Silvia de Souza Costa, Cynthia Cortes e Paulo Soares. Rio de Janeiro: Record, 2009.

DOBYNS, Henry F. An appraisal of techniques with a new hemisferic estimate. Current Antrhropology, Chicago, v. 7, n. 4, p. 395-416, Sept. 1966. DOI: https://doi.org/10.1086/200749.

HENIGE, David. Recent work and prospects in American Indian contact population. History Compass, Hoboken, v. 6, n. 1, p. 183-206, Jan. 2008. DOI: https://doi.org/10.1111/j.14780542.2007.00490.x.

JONES, David S. Population, health, and public welfare. In: HOXIE, Frederick E. The Oxford Handbook of American Indian History. Oxford: Oxford University Press, 2016. p. 413-435.

JONES, David S. Virgin soils revisited. The William and Mary Quarterly, Virginia, v. 60, n. 4, p. 703-742, Oct. 2003. DOI: https://doi.org/10.2307/3491697.

KOCH, Alexander; BRIERLEY, Chris; MASLIN, Mark M.; LEWIS, Simon L. Earth system impacts of the European arrival and Great Dying in the Americas after 1492. Quaternary Science Reviews, Amsterdam, v. 207, p. 13-36, Mar. 2019. DOI: https://doi. org/10.1016/j.quascirev.2018.12.004

LÉON-PORTILLA, Miguel. A visão dos vencidos: a tragédia da conquista narrada pelos astecas. Porto Alegre: L\&PM, 1985.

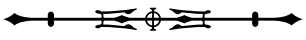


LIVI-BACCI, Massimo. The demise of the American Indios. Population and Development Review, Hoboken, v. 37, n. 1, p. 161-183, Mar. 2011. DOI: https://doi.org/10.1111/j.1728-4457.2011.00393.x.

LIVI-BACCI, Massimo. Conquista: a destruição dos índios americanos. Lisboa: Edições 70, 2007.

LIVI-BACCI, Massimo. The depopulation of Hispanic America after the Conquest. Population and Development Review, Hoboken, v. 32, n. 2, p. 199-232, June 2006. DOI: https://doi.org/10.1111/J.17284457.2006.00116.x.

LIVI-BACCI, Massimo. Las múltiples causas de la catástrofe: consideraciones teóricas y empíricas. Revista de Indias, Madrid, v. 63 , n. 227, p. 31-48, 2003. DOI: https://doi.org/10.3989/ revindias.2003.i227.550.

MACNEILL, William H. Plagues and peoples. New York: Anchor, 1976.

MALVIDO, Elsa. La epidemiología, una propuesta para explicar la despoblación americana. Revista de Indias, Madrid, v. 63, n. 227, p. 65-78, 2003. DOI: https://doi.org/10.3989/revindias.2003.i227.552.

MANN, Charles C. 1491: novas revelações das Américas antes de Colombo. Rio de Janeiro: Objetiva, 2007.

MAYR, Ernst. How to carry out the adaptationist program? The American Naturalist, Chicago, v. 121, n. 3, p. 324-334, Mar. 1983. DOI: https://doi.org/10.1086/284064.

MAYR, Ernst. Cause and effect in biology. Science, Washington, v. 134, n. 3489, p. 1501-1506, Nov. 1961. DOI: https://doi.org/10.1126/ science.134.3489.1501.

NASH, Linda. Beyond virgin soils: disease as environmental history. In: ISENBERG, Andrew C. (ed.). The Oxford handbook of environmental history. Oxford: Oxford University Press, 2014. p. 76-107.

NESSE, Randolph M.; WILLIAMS, George C. Por que adoecemos: a nova ciência da medicina darwinista. Rio de Janeiro: Campus, 1997.

NEWSON, Linda A. Indian population patterns in colonial Spanish America. Latin American Research Review, Pittsburgh, v. 20, n. 3, p. 41-74, Jan. 1985.

PERLMAN, Robert L. Evolution and medicine. Oxford: Oxford University Press, 2013.

PUENTE, José Luis; CALVA, Edmundo. The one health concept-the Aztec empire and beyond. Patogens and Disease, Oxford, v. 75, p. 1-2, June 2017. DOI: https://doi.org/10.1093/femspd/ftx062.
RESTALL, Matthew. Sete mitos da conquista espanhola. Rio de Janeiro: Civilização Brasileira, 2006.

SÁNCHEZ-ALBORNOZ, Nicolás. A população da América Espanhola colonial. In: BETHELL, Leslie (org.). História da América Latina: América Latina colonial. São Paulo: Edusp, 2012. v. 2, p. 23-55.

SÁNCHEZ-ALBORNOZ, Nicolás. El debate inagotable. Revista de Indias, Madrid, v. 63, n. 227, p. 9-18, 2003. DOI: https://doi. org/10.3989/revindias.2003.i227.548.

STEARNS, Stephen C.; MEDZHITOV, Ruslan. Evolutionary medicine. Sunderland: Sinauer Associates, 2016.

STOREY, Rebecca. Population decline during and after Conquest. In: NICHOLS, Deborah L.; POOL, Christopher A. (ed.).The Oxford Handbook of Mesoamerican Archaeology. Oxford: Oxford Press, 2012. p. 908-915. DOI: https://doi.org/10.1093/ oxfordhb/9780195390933.001.0001.

TODOROV, Tzvetan. A conquista da América: a questão do outro. São Paulo: WMF Martins Fontes, 2010.

VÅGENE, Åshild J.; HERBIG, Alexander; CAMPANA, Michael G.; ROBLES GARCÍA, Nelly M.; WARINER, Christine; SABIN, Susanna; SPYROU, Maria A.; ANDRADES VALTUEÑA, Aida; HUSON, Daniel; TUROSS, Noreen; BOS, Kirsten I.; KRAUSE, Johannes. Salmonella enterica genomes from victims of a major sixteenth-century epidemic in Mexico. Nature Ecology \& Evolution, London, v. 2, p. 520-528, Jan. 2018. DOI: https://doi.org/10.1038/ s41559-017-0446-6.

VILLAMARÍN, Juan; VILLAMARÍN, Judith. Native Colombia: contact, conquest and colonial populations. Revista de Indias, Madrid, v. 63, n. 227, p. 105-134, abr. 2003. DOI: https://doi.org/10.3989/ revindias.2003.i227.554.

WAIZBORT, Ricardo Francisco; LUZ, Maurício Roberto Motta Pinto da. Medicina evolutiva: incorporando a teoria da evolução na formação de profissionais de saúde brasileiros. Revista Brasileira de Educação Médica, Brasília, v. 41, n. 4, p. 487-496, dez. 2017. DOI: http://dx.doi.org/10.1590/1981-52712015v41n4rb20160074.

WILLIAMS, George C.; NESSE, Randolph M. The Dawn of Darwinian Medicine. The Quarterly Review of Biology, Chicago, v. 66, n. 1, p. 1-22, Mar. 1991. DOI: https://doi.org/10.1086/417048.

ZAMBARDINO, Rudolph A. Mexico's population in the Sixteenth Century: demographic anomaly or mathematical illusion? The Journal of Interdisciplinary History, Cambridge, v. 11, n. 1, p. 1-27, Summer 1980. DOI: https://doi.org/10.2307/202984.

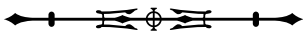


